\section{МОНГОЛЬСКАЯ РУКОПИСЬ «ЦАРЯ МОЛИТВ- УСТРЕМЛЕНИЙ О БЛАГОМ ПУТИ» («БХАДРАЧАРЬЯ») В ТУВИНСКОМ АРХИВЕ}

THE MONGOLIAN MANUSCRIPT OF THE «BHADRACARYA» (THE KING OF ASPIRATION PRAYERS, THE ASPIRATION FOR NOBLE EXCELLENT CONDUCT) FROM A TUVAN ARCHIVE

\section{С. В. Мирзаева}

Калмыцкий научный центр Российской академии наук, Российская Федерация

Цель статьи - введение в научный оборот анонимного монгольско$2 о$ перевода известного буддийского молитвенного текста «Царь молитв-устремлений о благом пути» («Бхадрачарья») из научного архива Тувинского института гуманитарных и прикладных социально-экономических исследований.

Автор описывает основные сведения о литературной истории этого памятника в традиции буддизма Махаяны, а также приводит основные отличия рассматриваемой монгольской рукописи от канонических переводов.

Приводится транслитерация рукописного текста на монгольском письме, снабженная параллельным переводом на русский язык.

Ключевые слова: Бхадрачарья; «Царь молитвустремлений о благом пути»; рукопись; монгольский язык; перевод; архив; ТИГПИ; Тува
Saglara V. Mirzaeva

Kalmyk Research Center, Russian Academy of Sciences, Russian Federation

The article introduces and examines an anomynous Mongolian translation of a well-known Buddhist prayer text «The King of Aspiration Prayers, The Aspiration for Noble Excellent Conduct» (Bhadracarya), preserved at the research archives of the Tuvan Institute for the Humanities and Socioeconomic Studies.

The author provides basic information on the literary history of this text within the tradition of the Mahayana Buddhism, listing the major variations between the manuscript text and canonical translations of the Bhadracarya.

Also provided is the transliteration of the text into contemporary Mongolian and a parallel Russian translation.

Keywords: Bhadracarya; «The King of Aspiration Prayers, The Aspiration for Noble Excellent Conduct»; manuscript; Mongolian language; translation; archives; TIHSES (TGGPI); Tuva

\footnotetext{
Мирзаева Саглара Викторовна - аспирант, научный сотрудник отдела монгольской филологии Калмыцкого научного центра Российской академии наук. Адрес: 358000, Россия, г. Элиста, ул. И. К. Илишкина, д. 8. Тел.: +7 (84722) 3-55-06. Эл. адрес: kundgabo@list.ru. Научный руководитель - к. филол. н. Д. Н. Музраева. ORCID: 0000-0002-8542-0260

Mirzaeva Saglara Viktorovna, Postgraduate student and Researcher, Department of Mongolian philology, Kalmyk Research Center, Russian Academy of Sciences. Postal address: 8 Ilishkin St., Elista 358000 Russian Federation. Tel.: +7 (84722) 3-55-06. Email: kungdabo@list.ru. Research adviser - Candidate of Philology D. N. Muzraeva.
} 


\section{Введение}

Предмет исследования данной статьи - один из наиболее популярных молитвенных текстов тибето-монгольского буддизма «Арья-бхадрачарья-пранидханараджа» (санскр. ārya-bhadracaryā-pranidhāna-rāja; тиб. 'phags pa bzang po spyod pa'i

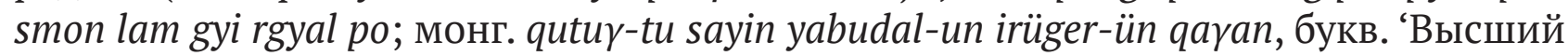
царь молитв-устремлений о благом пути’) (далее сокращенно - «Бхадрачарья» ${ }^{1}$ ). Это сочинение известно в тибетской традиции как «Зангчо монлам» (тиб. bzang spyod smon lam), в монголоязычной традиции - как «Ёрөөлийн хаан (Йөрәлин

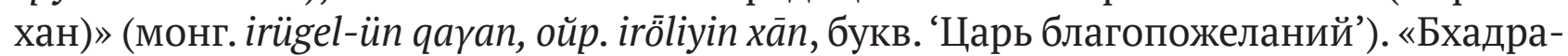
чарья» - один из наиболее популярных образцов жанра пранидхан, или молитвустремлений, в традиции буддизма Махаяны. Она представляет собой стихотворный текст из шестидесяти двух строф, содержащий устремление почитать всех будд и благодаря следованию по пути бодхисаттвы достичь Пробуждения ради блага всех живых существ.

Роль «Бхадрачарьи» в литературной традиции буддизма трудно переоценить. Созданный на рубеже IV-V вв. н. э. в Индии (Osto, 2010: 3), этот памятник множество раз переводился на различные языки, включая монгольские, породил обширную комментаторскую литературу и вплоть до настоящего времени применяется в буддийской практике. По мнению исследователя М. Капстейна, это едва ли не самый популярный текст в традиции тибетского буддизма (Kapstein, 2000: 97). Он широко представлен не только в письменной традиции, но и в эпиграфике и искусстве буддизма Махаяны.

Популярность этого текста в буддийской традиции объясняет большое количество его рукописных и ксилографических версий на тибетском и монгольском языках в фондохранилищах России, Монголии и других стран. В частности, в научном архиве Тувинского института гуманитарных и прикладных социально-экономических исследований (далее - НА ТИГПИ) хранятся четыре рукописных и четыре ксилографических текста на тибетском языке и одна рукописная версия «Бхадрачарьи» на монгольском языке.

Для нас большой интерес представляет монгольская рукопись «Бхадрачарьи», обозначенная в архиве как «Хутукт сайн явдалийн йиругил хаан оршиба» (монг.

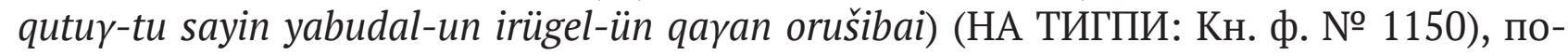
скольку в ней представлен перевод, отличный от канонических переводов, включенных в состав свода буддийского канона Ганджура ${ }^{2}$.

Помимо текстуальных различий, можно отметить, что в рассматриваемом рукописном тексте отсутствует четырнадцатая строфа, а также в конце текста содер-

\footnotetext{
1 Такое сокращенное название (англ. Bhadracarya / Bhadracari) используют европейские исследователи, изучающие роль данного текста в традициях Индии, Китая и Тибета, cм. Asmussen, 1961; Osto 1999, 2010.

2 Ганджур (тиб., букв. «слово [Будды]») - первая часть тибетского буддийского канона - собрания буддийских текстов, переведенных с санскрита, пракритов, китайского и других языков и восходящих к Будде Шакьямуни, его ученикам и комментаторской традиции (вторая часть канона - Данджур).
} 
жится отрывок, в котором излагается польза от чтения или переписывания «Бхадрачарьи», отсутствующий в основном тексте памятника.

В данной статье мы хотим привести транслитерацию памятника ${ }^{1}$, снабженную русским переводом, чтобы ввести его в научный оборот.



Фото 1. Титул рукописи «Хутукт сайн явдалийн йиругил хаан оршиба» (из Научного архива ТИГПИ).

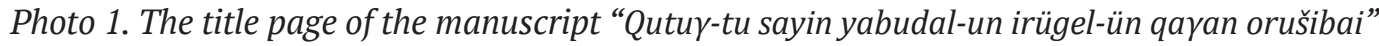
(from Research archives of TIGPI (TIHSES).

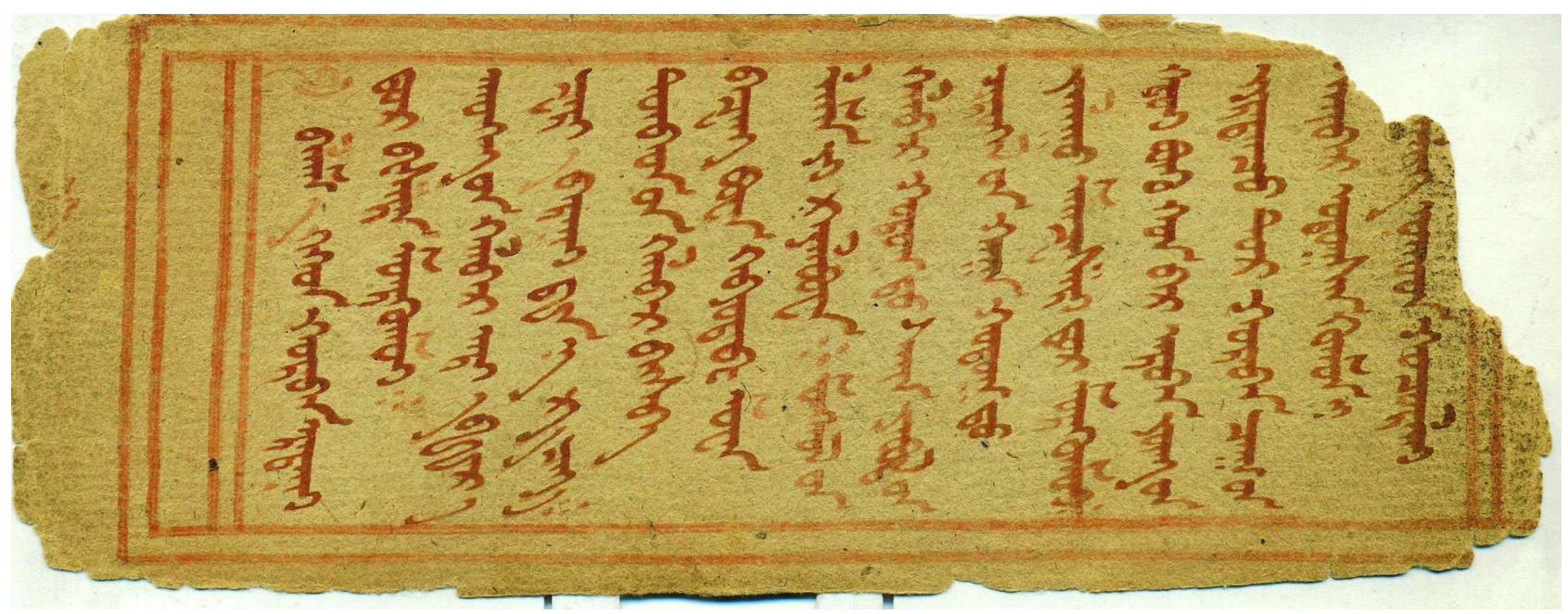

Фото 2. Страница 1а рукописи «Хутукт сайн явдалийн йиругил хаан оршиба» (из Научного архива ТИГПИ).

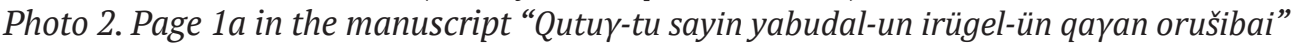
(from Research archives of TIGPI (TIHSES).

\footnotetext{
${ }^{1}$ Слова в квадратных скобках представляют собой восстановленные автором статьи формы в тех случаях, когда в силу физических характеристик рукописи невозможно прочесть то или иное слово. Слова, помещенные в фигурные скобки, вписаны автором рукописи между строк. Слова, приводимые в скобках со знаком равенства, вставлены автором статьи и передают, по его мнению, смысл текста более точно.
} 


\section{Транслитерация и русский перевод}

\begin{tabular}{|c|c|c|c|}
\hline $\begin{array}{c}\text { № } \\
\text { строфы }\end{array}$ & $\begin{array}{c}\text { Транслитерация монгольского } \\
\text { текста }\end{array}$ & $\begin{array}{c}\text { № } \\
\text { строфы }\end{array}$ & Русский перевод \\
\hline & 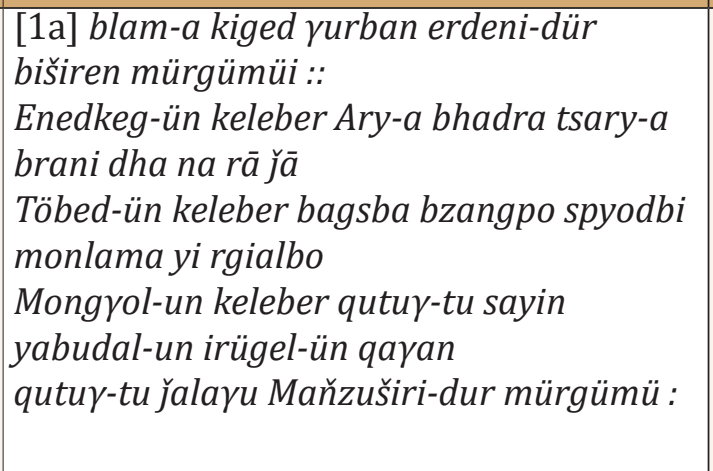 & & $\begin{array}{l}\text { С верой простираюсь перед учителем и } \\
\text { Тремя Драгоценностями. } \\
\text { На санскрите: Арья-бхадрачарья- } \\
\text { пранидхана-раджа. } \\
\text { На тибетском: пагсба бзангпо спьод би } \\
\text { монлам гьи ргьялпо. } \\
\text { На монгольском: хутугту сайн } \\
\text { ябудалун иругелун хаган. } \\
\text { Склоняюсь пред Благородным [вечно] } \\
\text { юным Манджушри ! }\end{array}$ \\
\hline$(1)$ & 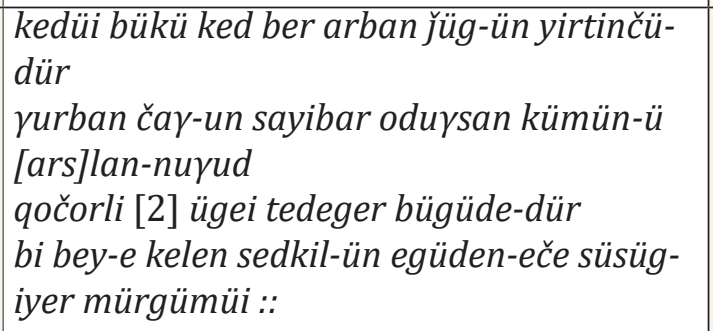 & $(1)$ & $\begin{array}{l}\text { Сколько бы ни было в мирах десяти } \\
\text { направлений [пространства] Сугат трех } \\
\text { времен }{ }^{2}, \text { Львов [среди] людей } \\
\text { Всем им без исключения телом, речью } \\
\text { и умом } \\
\text { С верой поклоняюсь. }\end{array}$ \\
\hline$(2)$ & 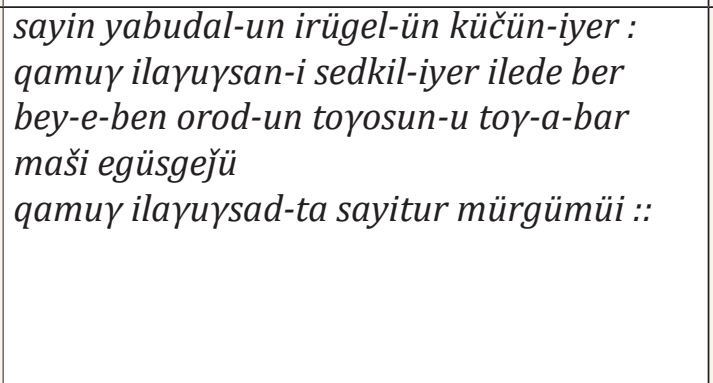 & $(2)$ & $\begin{array}{l}\text { Силой [моего] устремления о } \\
\text { благом пути } 9 \text { проявлю в уме всех } \\
\text { Победоносных }{ }^{5} \text {. } \\
\text { [Преумножая] свое тело столько раз, } \\
\text { сколько есть атомов }{ }^{6} \text { во [всех] Чистых } \\
\text { Землях }{ }^{7} \text { будд, } \\
\text { Склоняюсь перед всеми Победо- } \\
\text { носными. }\end{array}$ \\
\hline (3) & 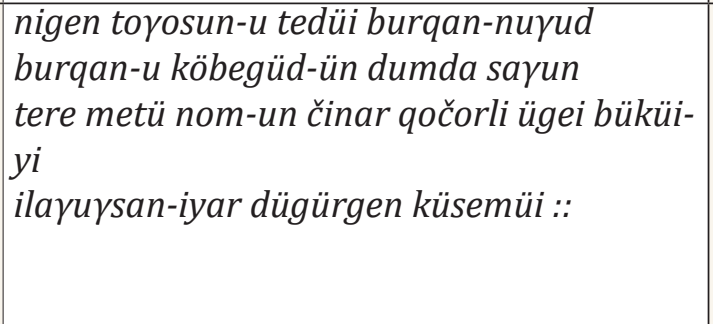 & (3) & $\begin{array}{l}\text { [Представляя], что на одном атоме } \\
\text { будды, числом равные количеству } \\
\text { атомов [во всех Чистых Землях], } \\
\text { Восседают среди своих сыновей } \\
\text { Я желаю наполнить все дхармадхатуํ․ } \\
\text { Полностью без остатка } \\
\text { Победоносными. }\end{array}$ \\
\hline
\end{tabular}

\footnotetext{
${ }^{1}$ Манджушри - бодхисаттва мудрости.

${ }^{2}$ Сугаты трех времен - эпитет будд.

${ }^{3}$ Львы среди людей - эпитет будд.

${ }^{4}$ Благой путь - благие деяния, синоним деяний бодхисаттвы.

${ }^{5}$ Победоносный - эпитет Будды.

${ }^{6}$ Атом - пылинка, мельчайшая частица.

${ }^{7}$ Чистая Земля - мир, сфера, обитель будд, Поле будд.

${ }^{8}$ Сын Будд - эпитет бодхисаттвы.

9 Дхармадхату - пространство истинной реальности, синоним шуньяты.
} 


\begin{tabular}{|c|c|c|c|}
\hline (4) & 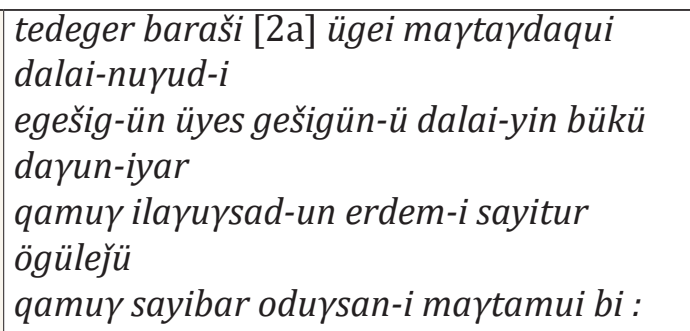 & (4) & $\begin{array}{l}\text { Неистощимыми океанами восхвале- } \\
\text { ний, } \\
\text { Голосами, [наделенными] океаном } \\
\text { качеств благозвучной речи, } \\
\text { Воспеваю я там благие качества всех } \\
\text { Победоносных } \\
\text { И восхваляю всех Сугат. }\end{array}$ \\
\hline (5) & 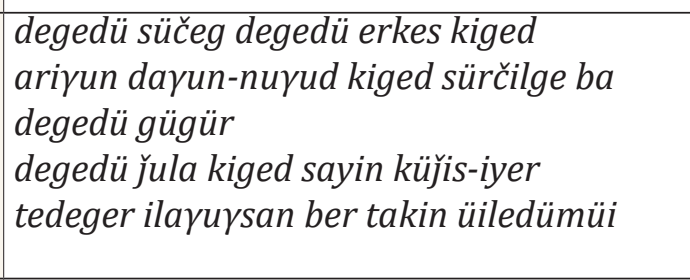 & (5) & $\begin{array}{l}\text { Тем Победоносным я совершаю под- } \\
\text { ношения } \\
\text { Лучшими цветами и четками, } \\
\text { Прекрасными голосами, воскурениями, } \\
\text { Чудесными светильниками и восхи- } \\
\text { тительными благовониями. }\end{array}$ \\
\hline (6) & 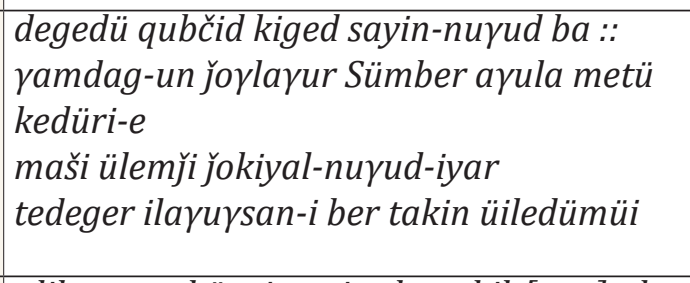 & $(6)$ & $\begin{array}{l}\text { Тем Победоносным я также совершаю } \\
\text { подношения } \\
\text { Лучшими одеяниями, } \\
\text { Яствами размером с гору Сумеру } \\
\text { И лучшими из всех выдающихся } \\
\text { проявлений. }\end{array}$ \\
\hline (7) & 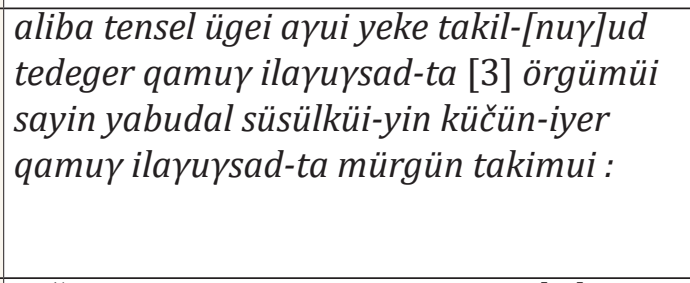 & (7) & $\begin{array}{l}\text { Все наивысшие и обширнейшие } \\
\text { подношения } \\
\text { Подношу всем Победоносным. } \\
\text { Силой моей веры в благой путь } \\
\text { Перед всеми Победоносными я } \\
\text { простираюсь и совершаю подношения. }\end{array}$ \\
\hline (8) & 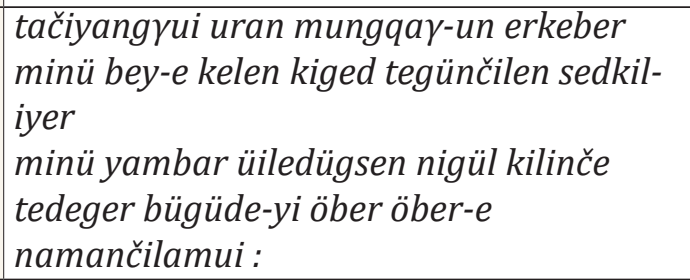 & (8) & $\begin{array}{l}\text { Я раскаиваюсь в каждом неблагом } \\
\text { деянии, } \\
\text { Совершенном мной телом, речью, } \\
\text { А также умом в силу привязанности, } \\
\text { Гнева и неведения. }\end{array}$ \\
\hline (9) & 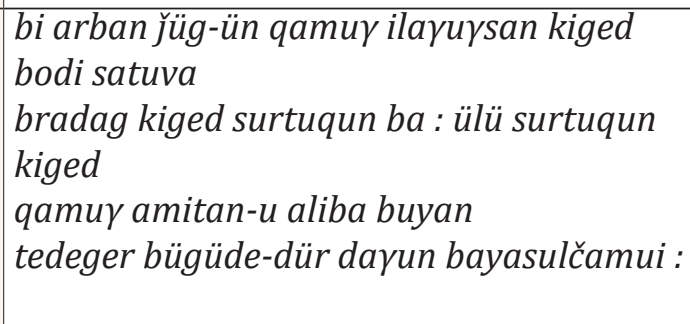 & $(9)$ & $\begin{array}{l}\text { Я сорадуюсь всем благим заслугам, } \\
\text { [накопленным] } \\
\text { Всеми Победоносными десяти } \\
\text { направлений, бодхисаттвами, } \\
\text { Пратьекабуддами르, обучающимся и } \\
\text { вышедшими за пределы обучения } \\
\text { И всеми живыми существами. }\end{array}$ \\
\hline$(10)$ & 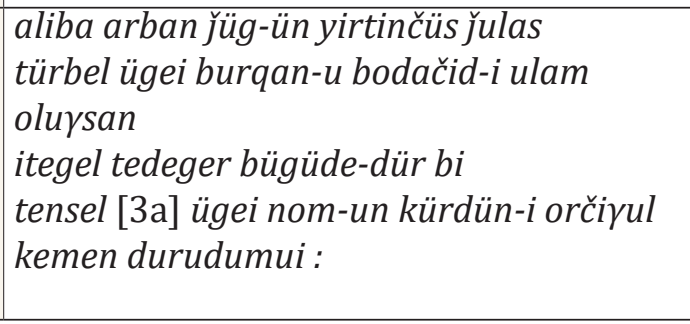 & $(10)$ & $\begin{array}{l}\text { Сколько [бы ни было] Светочей миров } \\
\text { десяти направлений, } \\
\text { Обретших беспрепятственно состояние } \\
\text { будды, } \\
\text { Всех этих Защитников }{ }^{4} \text { молю я } \\
\text { Вращать непревзойденное колесо } \\
\text { Учения. }\end{array}$ \\
\hline
\end{tabular}

${ }^{1}$ Сумеру - священная гора в буддийской космологии, располагающаяся в центре вселенной.

${ }^{2}$ Пратьекабудда - в ранних буддийских текстах человек, достигший Пробуждения без помощи духовного учителя и не передающий свои знания другим.

${ }^{3}$ Светоч мира - эпитет Будды.

${ }^{4}$ Защитник - эпитет будд, бодхисаттв, йидамов и т. д. 


\begin{tabular}{|c|c|c|c|}
\hline$(11)$ & 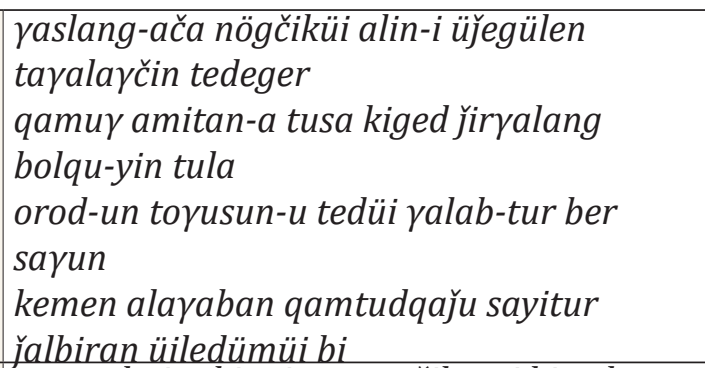 & $(11)$ & $\begin{array}{l}\text { Сложив ладони [у сердца], молю } \\
\text { Тех, кто намерен явить уход в нирвану, } \\
\text { И прошу ради пользы и блага всех } \\
\text { живых существ } \\
\text { Пребывать [здесь] столько кальп }{ }^{1}, \\
\text { сколько есть атомов в Чистых Землях } \\
\text { будд. }\end{array}$ \\
\hline (12) & 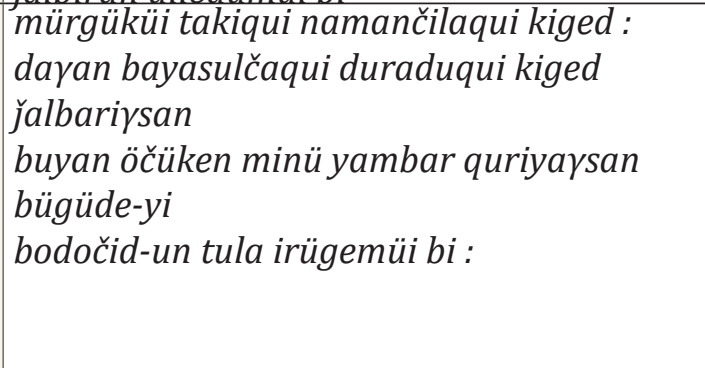 & $(12)$ & $\begin{array}{l}\text { Все благие заслуги, накопленные мной } \\
\text { благодаря } \\
\text { Выражению почтения, подношению, } \\
\text { раскаянию, сорадованию, } \\
\text { Просьбами повернуть колесо Учения и } \\
\text { не покидать сансару, } \\
\text { Сколько бы их ни было, я посвящаю } \\
\text { [достижению] Пробуждения. }\end{array}$ \\
\hline (13) & 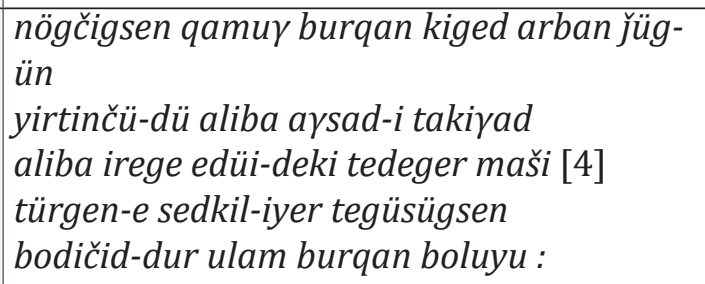 & $(13)$ & $\begin{array}{l}\text { Пусть я совершу подношения всем } \\
\text { буддам прошлого } \\
\text { [И настоящего], пребывающим сейчас в } \\
\text { мирах десяти направлений! } \\
\text { Пусть все [будды] будущего очень } \\
\text { быстро обретут состояние будды! }\end{array}$ \\
\hline 14 & отсутствует & & \\
\hline (15) & 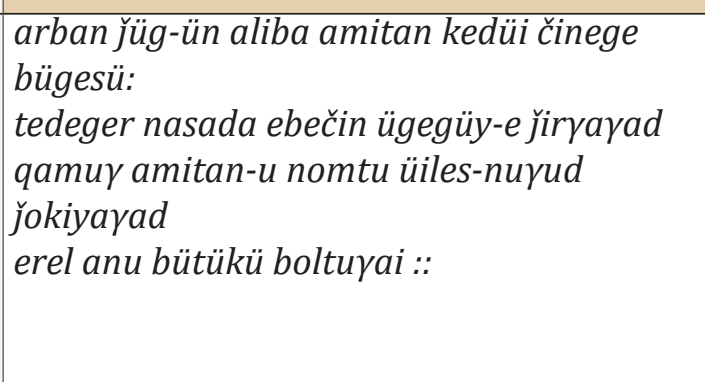 & $(15)$ & $\begin{array}{l}\text { Пусть все живые существа десяти } \\
\text { направлений, сколько бы их ни было, } \\
\text { Будут всегда свободны от болезней и } \\
\text { счастливы! } \\
\text { Пусть благие цели всех существ, } \\
\text { связанные с Учением, } \\
\text { Будут [исполнены] в гармонии, как и их } \\
\text { желания! }\end{array}$ \\
\hline (16) & 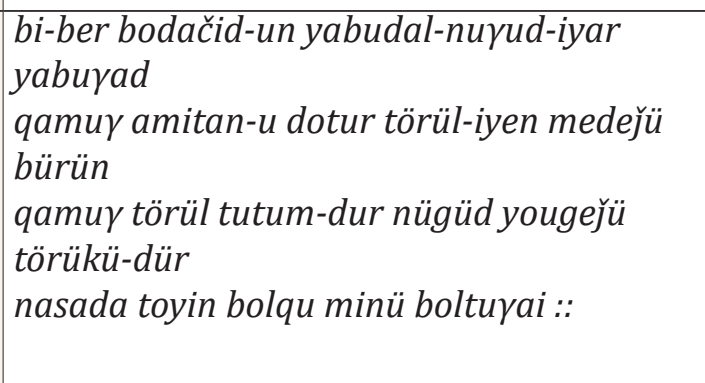 & $(16)$ & $\begin{array}{l}\text { Пусть я, практикуя благим образом } \\
\text { деяния бодхисаттв, } \\
\text { Во всех рождениях буду помнить свои } \\
\text { жизни! } \\
\text { Пусть во всех жизнях, [переживая] } \\
\text { умирание и новое рождение, } \\
\text { Я всегда буду принимать монашеские } \\
\text { обеты! }\end{array}$ \\
\hline (17) & 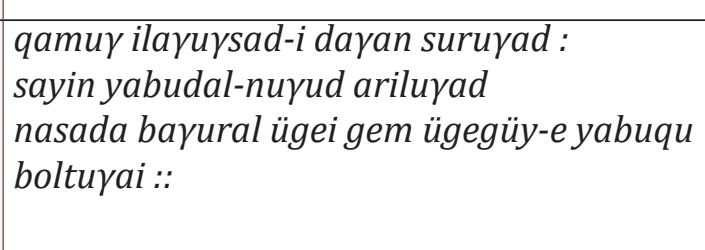 & $(17)$ & $\begin{array}{l}\text { Пусть, обучаясь и следуя [примеру] всех } \\
\text { Победоносных, } \\
\text { Я таким образом очищу благие деяния! } \\
\text { Пусть я всегда буду свободен от } \\
\text { нарушений и изъянов! }\end{array}$ \\
\hline
\end{tabular}

${ }^{1}$ Кальпа - космический цикл, время от возникновения мира до его гибели. 


\begin{tabular}{|c|c|c|c|}
\hline (18) & 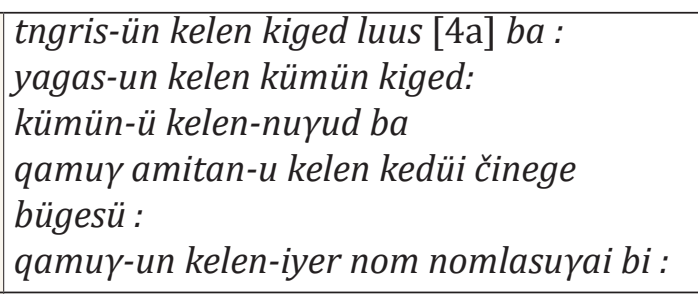 & (18) & $\begin{array}{l}\text { Пусть я смогу объяснять Учение на всех } \\
\text { существующих языках } \\
\text { Всех живых существ, сколько бы их ни } \\
\text { было, - } \\
\text { Языках небожителей }{ }^{1}, \text { нагов }^{2}, \\
\text { Якшей }{ }^{3} \text { и людей! }\end{array}$ \\
\hline (19) & 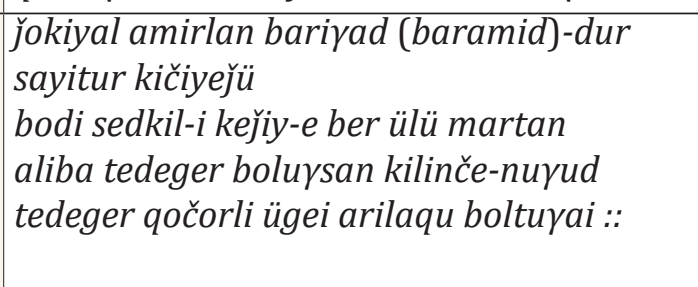 & (19) & $\begin{array}{l}\text { [Делая свой ум] более спокойным и } \\
\text { усердствуя в парамитах }{ }^{4} \\
\text { Пусть я никогда не забуду о бодхичитте! } \\
\text { Пусть я очищу таким образом все без } \\
\text { остатка } \\
\text { Неблагие деяния! }\end{array}$ \\
\hline$(20)$ & 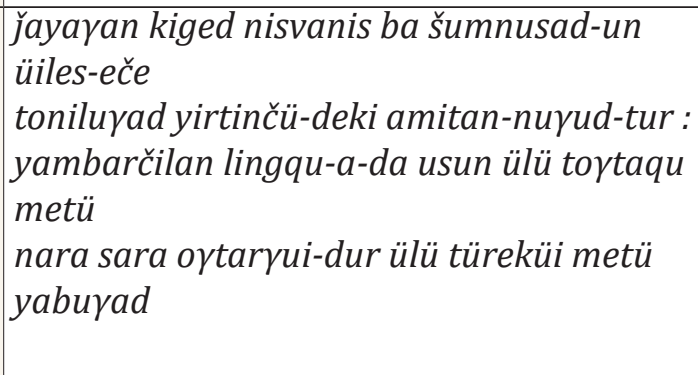 & $(20)$ & $\begin{array}{l}\text { Пусть я освобожусь от [негативной] } \\
\text { кармы, клеш }{ }^{5} \text { и деяний мар } \\
\text { И [моя жизнь] во всех рождениях [этого] } \\
\text { мира, словно лотос, } \\
\text { [К которому] не пристают [грязь] и вода, } \\
\text { будет подобна } \\
\text { Солнцу и луне, беспрепятственно } \\
\text { перемещающимся по небу! }\end{array}$ \\
\hline$(21)$ & 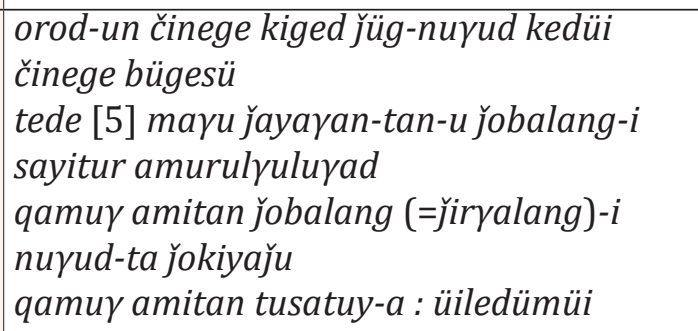 & (21) & $\begin{array}{l}\text { Пусть во всех без остатка направлениях } \\
\text { и масштабах Чистых Земель, } \\
\text { Сколько бы их ни было, я благим } \\
\text { образом умиротворю } \\
\text { Страдания плохих рождений, приведу } \\
\text { всех живых существ } \\
\text { К счастью и буду приносить им пользу! }\end{array}$ \\
\hline (22) & 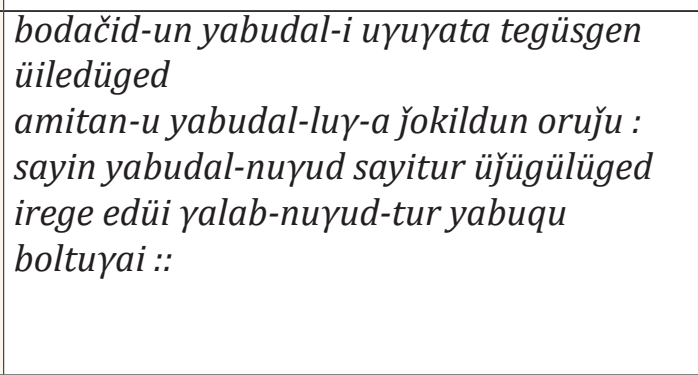 & $(22)$ & $\begin{array}{l}\text { Да исполню я совершенным образом } \\
\text { деяния бодхисаттвы, } \\
\text { И, поступая в соответствии с } \\
\text { деятельностью живых существ } \\
\text { И показывая совершенным образом } \\
\text { благой путь, } \\
\text { Буду практиковать его в грядущих } \\
\text { кальпах! }\end{array}$ \\
\hline (23) & 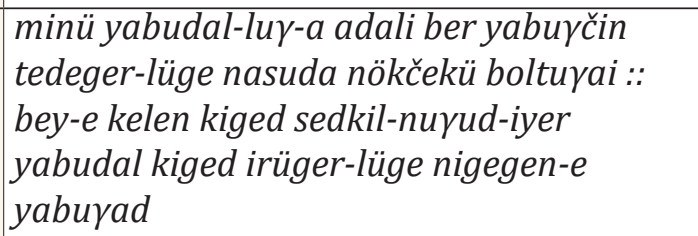 & (23) & $\begin{array}{l}\text { Пусть меня всегда будут окружать те, } \\
\text { Чьи деяния подобны моим, } \\
\text { И на уровнях тела, речи, а также ума } \\
\text { Наши деяния будут едины с нашими } \\
\text { молитвами-устремлениями! }\end{array}$ \\
\hline
\end{tabular}

${ }^{1}$ Небожители - один из трех благих уделов, куда также входят мир асуров и мир людей.

${ }^{2}$ Наги - мифологические существа, обитающие в водоемах, с головой человека и телом змеи.

${ }^{3}$ Якши - один из восьми классов полубожественных демонических существ, которые в индийской мифологии являются хранителями сокрытых в земле сокровищ и входят в свиту хранителя севера Куберы.

${ }^{4}$ Парамита - запредельное совершенство, наивысшая добродетель, практикуемая бодхисаттвами.

${ }^{5}$ Клеша - тревожащие эмоции, неблагоприятные для духовного совершенствования факторы сознания, которые препятствуют постижению истины и вызывают страдания.

${ }^{6}$ Мары - неблагоприятные факторы, препятствующие реализации в практике. 


\begin{tabular}{|c|c|c|c|}
\hline$(24)$ & 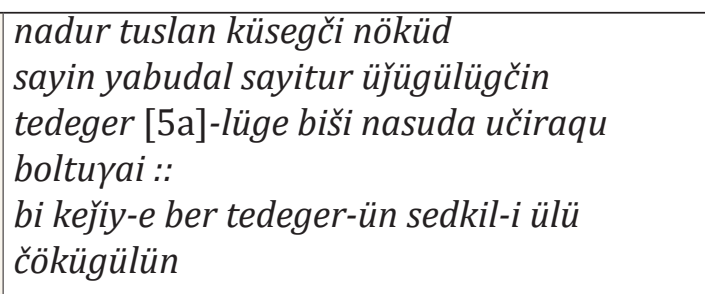 & (24) & $\begin{array}{l}\text { Пусть я всегда буду окружен } \\
\text { Друзьями, которые, желая принести мне } \\
\text { пользу, } \\
\text { Превосходно являют благой путь, } \\
\text { И никогда их не разочарую! }\end{array}$ \\
\hline (25) & 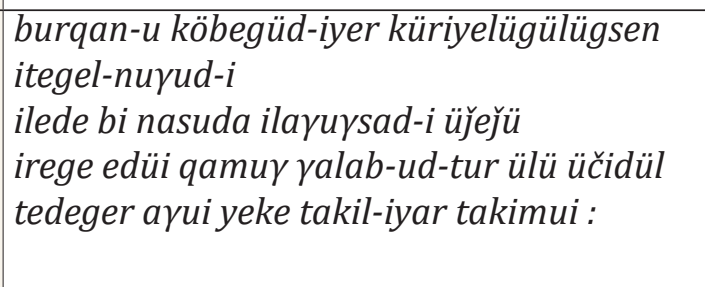 & $(25)$ & $\begin{array}{l}\text { Пусть я всегда буду созерцать перед } \\
\text { собой Защитников в окружении } \\
\text { сыновей будд! } \\
\text { Пусть в грядущих кальпах без уныния } \\
\text { Я буду совершать им обширные } \\
\text { подношения! }\end{array}$ \\
\hline$(26)$ & 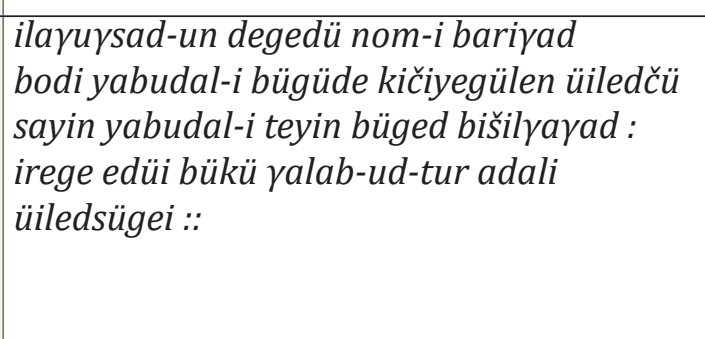 & (26) & $\begin{array}{l}\text { Храня [в уме] высшее Учение } \\
\text { Победоносных, } \\
\text { Пусть я буду усердствовать в деяниях } \\
\text { бодхисаттв } \\
\text { И, испытывая веру в него, буду } \\
\text { практиковать } \\
\text { Благой путь во всех грядущих кальпах! }\end{array}$ \\
\hline (27) & 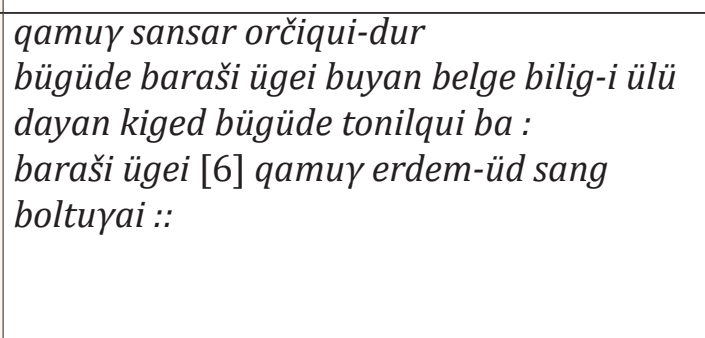 & (27) & $\begin{array}{l}\text { Пусть в [различных] рождениях в } \\
\text { сансаре }^{1} \\
\text { Я обрету неисчерпаемую высшую } \\
\text { мудрость и благие заслуги! } \\
\text { Пусть я стану неисчерпаемой } \\
\text { сокровищницей всех благих качеств, } \\
\text { дхьяны }^{2} \text { и Освобождения! }\end{array}$ \\
\hline$(28)$ & 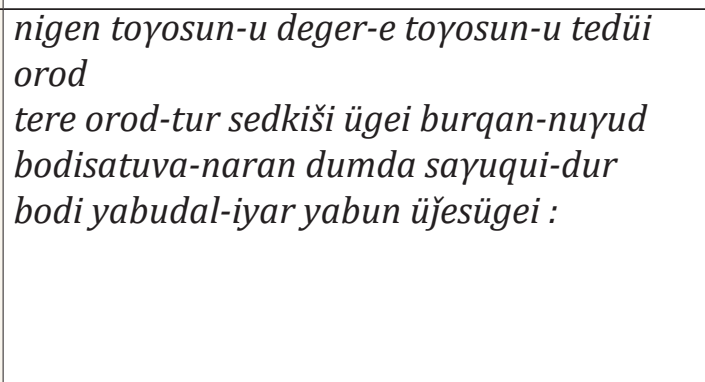 & (28) & $\begin{array}{l}\text { Пусть, практикуя деяния бодхисаттв, я } \\
\text { смогу увидеть воочию } \\
\text { Невообразимое [количество] будд, } \\
\text { пребывающих в окружении бодхисаттв, } \\
\text { Во всех Чистых Землях, [существующих] } \\
\text { в одном атоме, } \\
\text { Числом равных количеству атомов во } \\
\text { [всех] Чистых Землях! }\end{array}$ \\
\hline (29) & 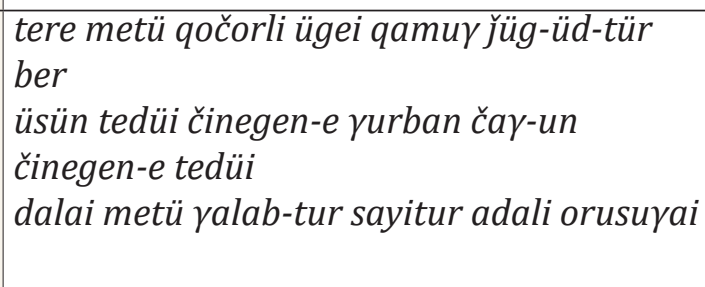 & (29) & $\begin{array}{l}\text { Пусть я смогу практиковать [понимание } \\
\text { того], } \\
\text { Что во всех направлениях, даже на } \\
\text { [кончике] волоска, в трех временах } \\
\text { [Может] пребывать океан будд [на } \\
\text { протяжении] океанов кальп! }\end{array}$ \\
\hline
\end{tabular}

\footnotetext{
${ }^{1}$ Сансара - круговорот существования, проявленное бытие, процесс непрерывного перерождения живых существ в шести мирах, главной характеристикой которого является страдание.

${ }^{2}$ Дхьяна - однонаправленная концентрация, когда ум не отвлекается и не оскверняется тревожащими эмоциями-клешами. Синоним самадхи.

${ }^{3}$ Освобождение - синоним нирваны.
} 


\begin{tabular}{|c|c|c|c|}
\hline (30) & 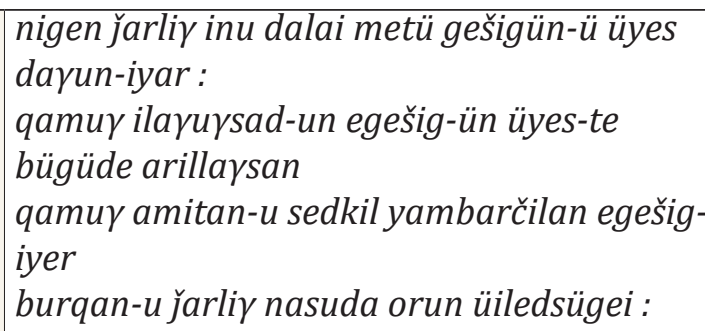 & $(30)$ & $\begin{array}{l}\text { Пусть я всегда [смогу] постигать речь } \\
\text { будд, } \\
\text { Одно слово [которой] заключает в себе } \\
\text { океан благих качеств, } \\
\text { Наделено чистотой речи Победоносных } \\
\text { И исполняет желания живых существ! }\end{array}$ \\
\hline (31) & 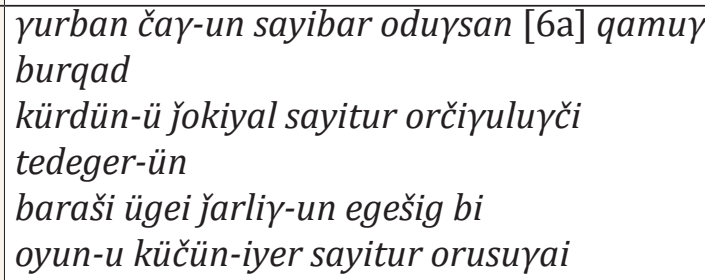 & (31) & $\begin{array}{l}\text { Пусть я смогу постичь умом } \\
\text { Неисчерпаемые мелодии высших } \\
\text { Учений } \\
\text { Всех будд - Сугат прошлого, } \\
\text { настоящего и будущего, } \\
\text { Вращающих колесо Учения! }\end{array}$ \\
\hline (32) & 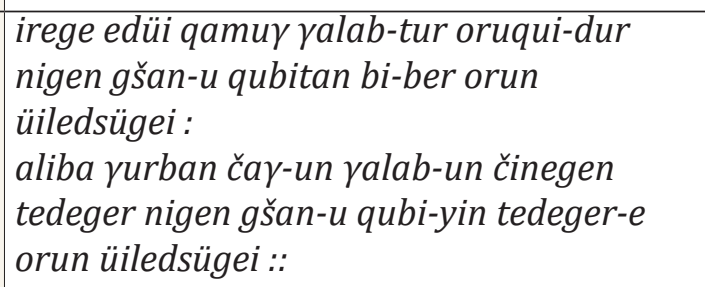 & $(32)$ & $\begin{array}{l}\text { Пусть я вступлю во все грядущие } \\
\text { кальпы } \\
\text { Лишь за одно мгновение! } \\
\text { Пусть я вступлю во все кальпы трех } \\
\text { времен } \\
\text { Лишь за одно мгновение! }\end{array}$ \\
\hline (33) & 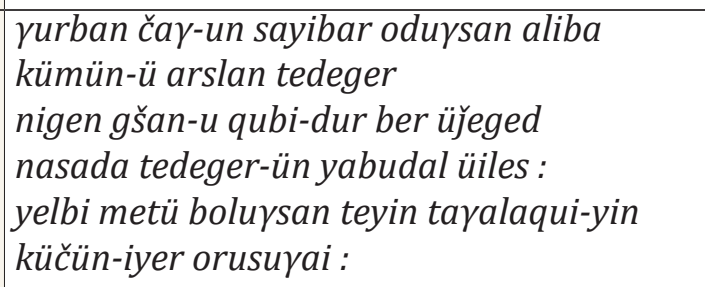 & (33) & $\begin{array}{l}\text { Пусть я [смогу] увидеть в один миг } \\
\text { Львов [среди] людей, Сугат прошлого, } \\
\text { настоящего и будущего, } \\
\text { И всегда [вступать] в сферу их деяний }{ }^{1} \\
\text { Силой, подобной иллюзии! }\end{array}$ \\
\hline (34) & 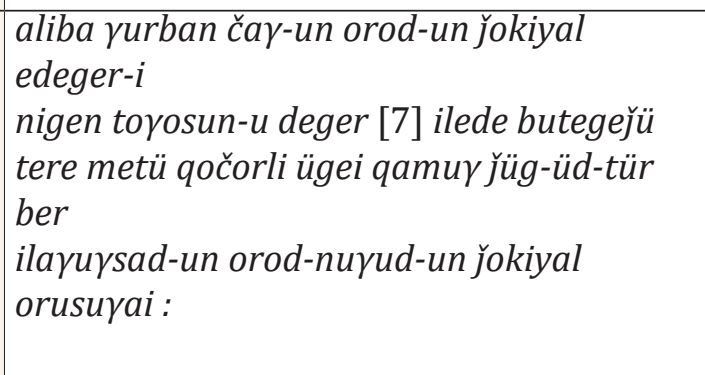 & $(34)$ & $\begin{array}{l}\text { Пусть я [смогу] практиковать, что в } \\
\text { одном-единственном атоме } \\
\text { [Могут] находиться [все] Чистые Земли } \\
\text { прошлого, настоящего и будущего! } \\
\text { Таким же образом, пусть я [смогу] } \\
\text { вступить } \\
\text { Во все Земли Победоносных во всех без } \\
\text { исключения направлениях! }\end{array}$ \\
\hline (35) & 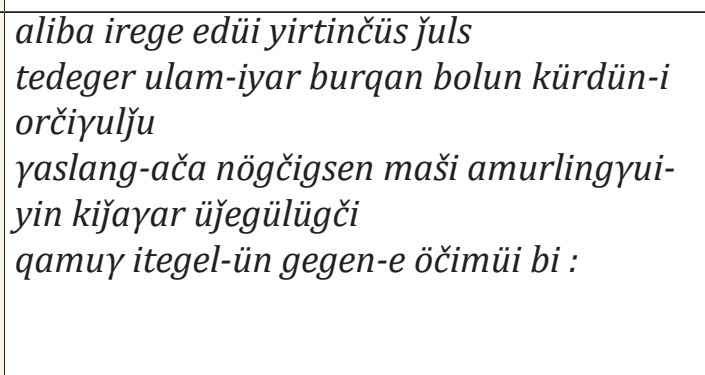 & (35) & $\begin{array}{l}\text { Пусть я [всегда] буду рядом с } \\
\text { Защитниками, } \\
\text { [Которые] в будущем станут Светочами } \\
\text { мира и, пройдя ступени [пути] } \\
\text { Пробуждения, } \\
\text { Будут вращать колесо Учения } \\
\text { И явят достижение нирваны, подобной } \\
\text { полному покою! }\end{array}$ \\
\hline
\end{tabular}

${ }^{1}$ Сфера деяний - сфера активности будд. 


\begin{tabular}{|c|c|c|c|}
\hline$(36)$ & 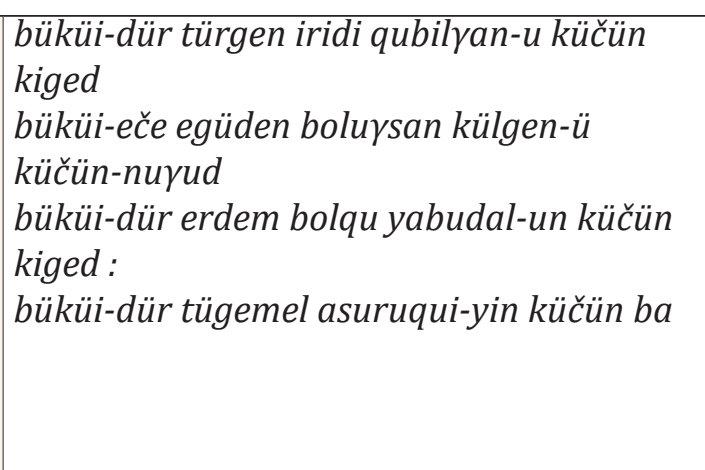 & $(36)$ & $\begin{array}{l}\text { Да овладею я в совершенстве [десятью } \\
\text { силами]: } \\
\text { Наивысшей силой риддхиํㅡㅁㅎтрого } \\
\text { [перемещения], } \\
\text { Наивысшей силой колесницы, ставшей } \\
\text { вратами, } \\
\text { Наивысшей силой пути, } \\
\text { [преисполненного] благих качеств, } \\
\text { Силой всепроникающей любящей } \\
\text { доброты, }\end{array}$ \\
\hline (37) & 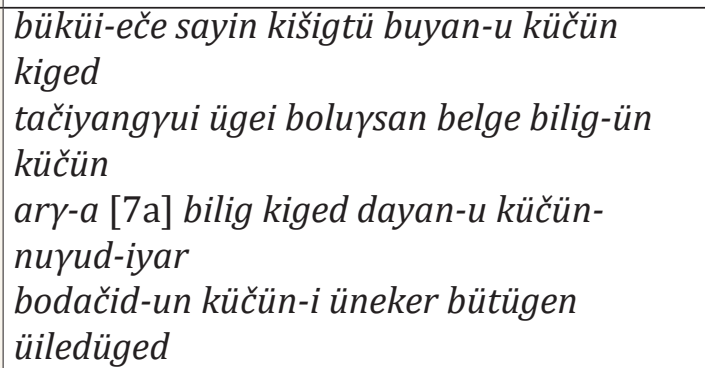 & (37) & $\begin{array}{l}\text { Наивысшей добродетельной силой } \\
\text { благой заслуги, } \\
\text { Силой высшей мудрости джняны, } \\
\text { свободной от привязанности, } \\
\text { Силой мудрости, метода и дхьяны, } \\
\text { А также силой Пробуждения! }\end{array}$ \\
\hline (38) & 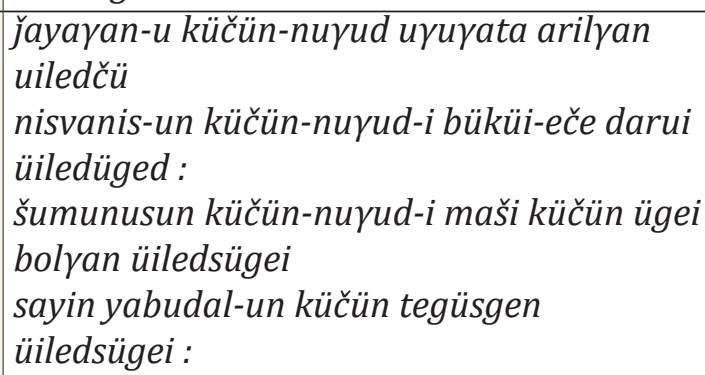 & (38) & $\begin{array}{l}\text { Пусть я таким образом очищу силу } \\
\text { [негативной] кармы, } \\
\text { Уничтожу силу клеш, } \\
\text { Лишу мар их власти } \\
\text { И в совершенстве овладею силой } \\
\text { благого пути! }\end{array}$ \\
\hline (39) & 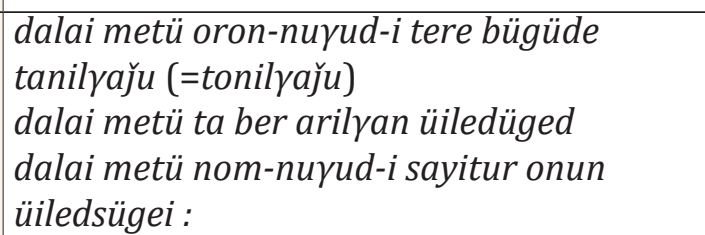 & (39) & $\begin{array}{l}\text { Пусть я освобожу все океаны } \\
\text { Чистых Земель, } \\
\text { Очищу их } \\
\text { И постигну океаны Учений! }\end{array}$ \\
\hline$(40)$ & 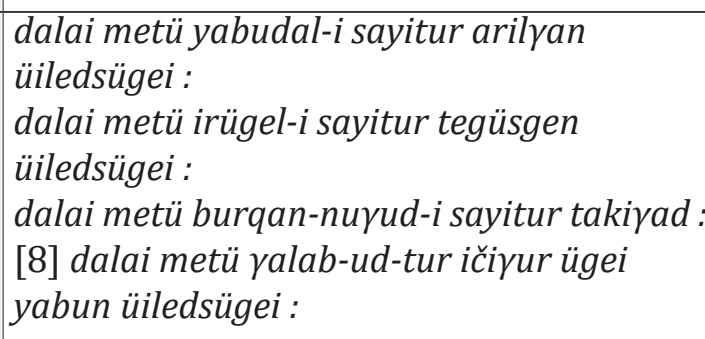 & $(40)$ & $\begin{array}{l}\text { Пусть я очищу океаны деяний, } \\
\text { Исполню в совершенстве океаны } \\
\text { молитв-устремлений, } \\
\text { Сотворю подношения океанам будд, } \\
\text { И буду действовать без стеснения на } \\
\text { протяжении океанов кальп! }\end{array}$ \\
\hline (41) & 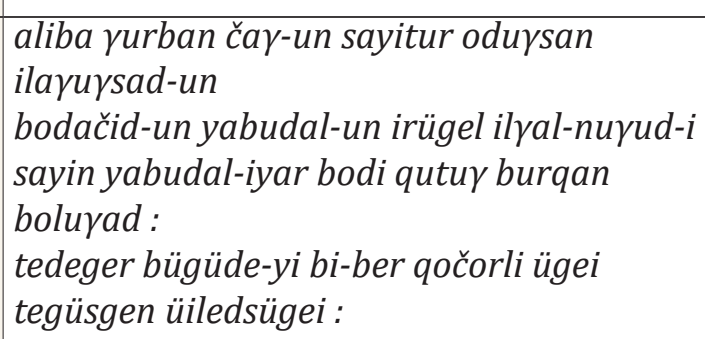 & $(41)$ & $\begin{array}{l}\text { Пусть я в совершенстве полностью } \\
\text { исполню все молитвы-устремления } \\
\text { О пути бодхисаттв, которые каждый из } \\
\text { Победоносных, } \\
\text { Прошествовавших в трех временах, } \\
\text { Практиковал и с помощью благих } \\
\text { деяний достиг Пробуждения! }\end{array}$ \\
\hline
\end{tabular}

${ }^{1}$ Риддхи - сверхъестественные магические способности. 


\begin{tabular}{|c|c|c|c|}
\hline (42) & 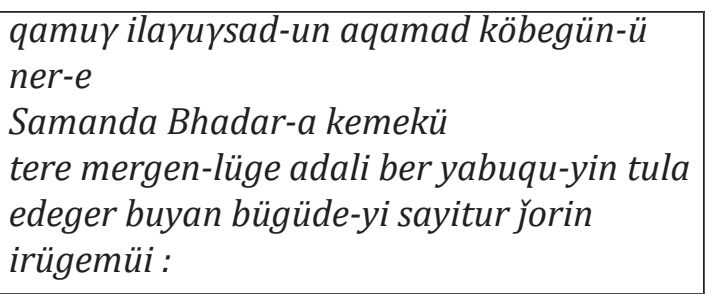 & $(42)$ & $\begin{array}{l}\text { Я посвящаю все свои заслуги тому, } \\
\text { Чтобы действовать так же искусно, } \\
\text { Как старший сын всех Победоносных, } \\
\text { Имя которого - Самантабхадра }{ }^{1} .\end{array}$ \\
\hline (43) & 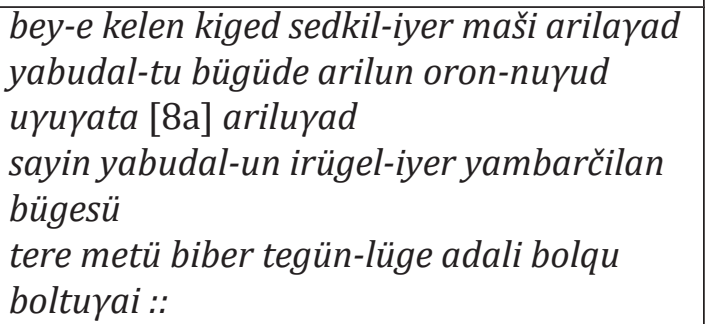 & $(43)$ & $\begin{array}{l}\text { Пусть стану я подобен ему, } \\
\text { Очистив тело, речь и ум, } \\
\text { Деяния и Чистые Земли } \\
\text { И став искусным даже в благом } \\
\text { посвящении заслуг! }\end{array}$ \\
\hline$(44)$ & 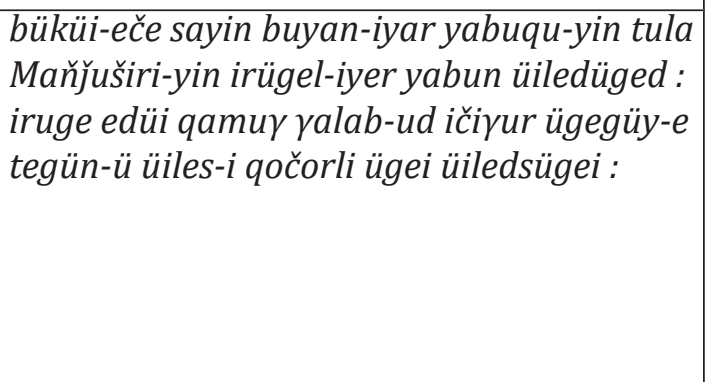 & $(44)$ & $\begin{array}{l}\text { Пусть я буду практиковать молитву- } \\
\text { устремление Манджушри } \\
\text { Ради [практики] полностью } \\
\text { добродетельного благого пути } \\
\text { И без стеснения во всех грядущих } \\
\text { кальпах } \\
\text { В совершенстве исполню все его деяния } \\
\text { без остатка! }\end{array}$ \\
\hline$(45)$ & 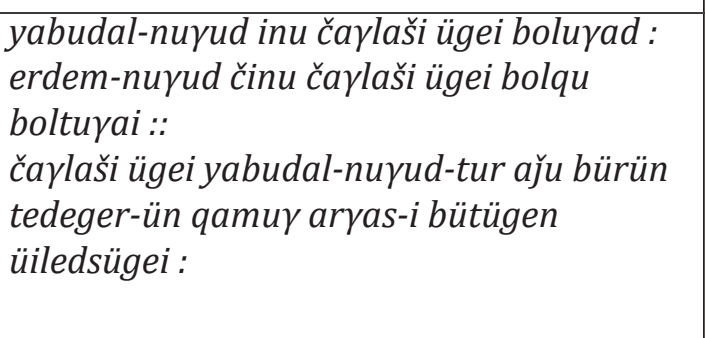 & $(45)$ & $\begin{array}{l}\text { Пусть мои деяния будут безмерны! } \\
\text { Пусть мои благие качества также будут } \\
\text { неизмеримы! } \\
\text { Пребывая в [состоянии] безмерных } \\
\text { деяний, } \\
\text { Пусть я познаю все их чудесные } \\
\text { воплощения! }\end{array}$ \\
\hline$(46)$ & 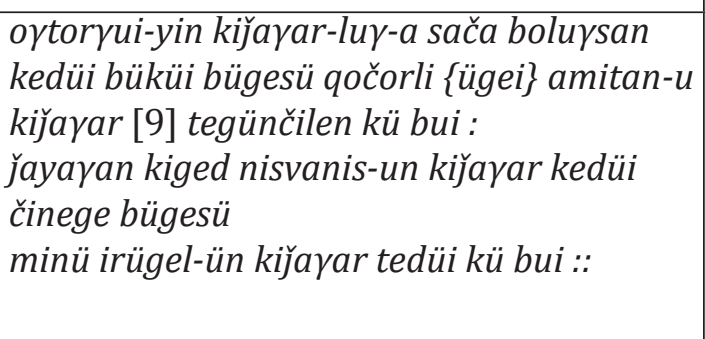 & $(46)$ & $\begin{array}{l}\text { Живые существа столь же бесконечны, } \\
\text { Как безграничны пределы } \\
\text { пространства. } \\
\text { Пусть моя молитва-устремление будет } \\
\text { столь же безгранична, } \\
\text { Как пределы [негативной] кармы и } \\
\text { клеш [живых существ]! }\end{array}$ \\
\hline$(47)$ & 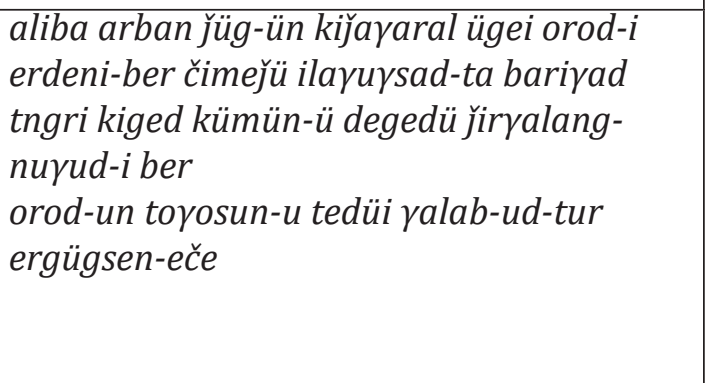 & $(47)$ & $\begin{array}{l}\text { Если те, кто услышит эту [сутру] — Царь } \\
\text { молитв-устремлений, } \\
\text { Будут следовать высшему пути } \\
\text { Пробуждения } \\
\text { И хотя бы один раз взрастят веру [в } \\
\text { него], } \\
\text { Они [обретут] высшую заслугу, } \\
\text { превышающую }\end{array}$ \\
\hline
\end{tabular}

${ }^{1}$ Самантабхадра - один из восьми главных бодхисаттв буддизма Махаяны, олицетворяющий доброту или счастье. 


\begin{tabular}{|c|c|c|c|}
\hline$(48)$ & 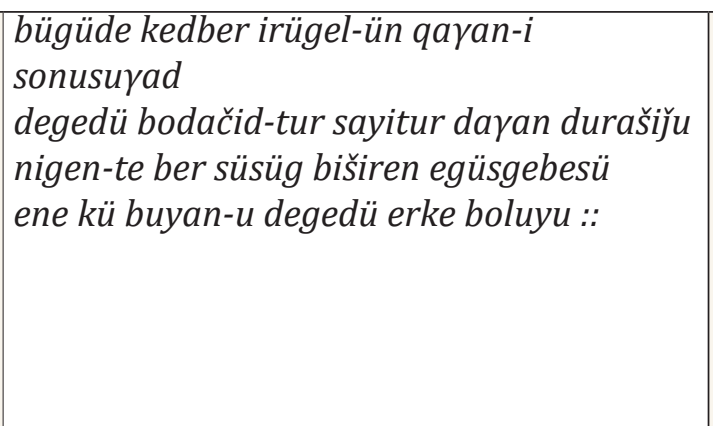 & (48) & $\begin{array}{l}\text { Подношение Победоносным всех } \\
\text { безграничных Чистых Земель } \\
\text { Десяти направлений, украшенных } \\
\text { драгоценностями, } \\
\text { Или подношение [им] высочайших } \\
\text { наслаждений людей и богов } \\
\text { [На протяжении] стольких кальп, } \\
\text { сколько есть атомов в Чистых Землях } \\
\text { будд. }\end{array}$ \\
\hline$(49)$ & 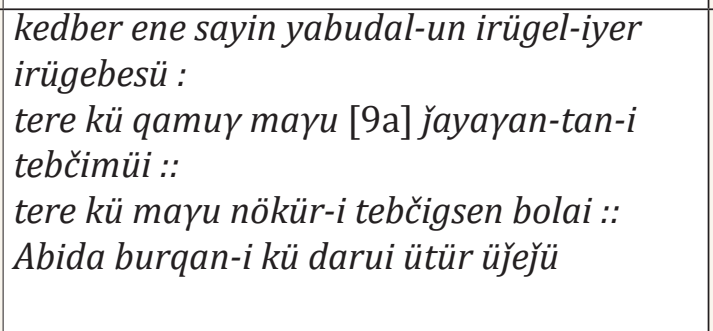 & (49) & $\begin{array}{l}\text { Те, кто произнесет эту молитву- } \\
\text { устремление о благом пути, } \\
\text { [Смогут] избежать рождения во всех } \\
\text { неблагих уделах } \\
\text { И плохих спутников } \\
\text { И в силу этого быстро увидят Будду } \\
\text { Амитабху². }\end{array}$ \\
\hline$(50)$ & 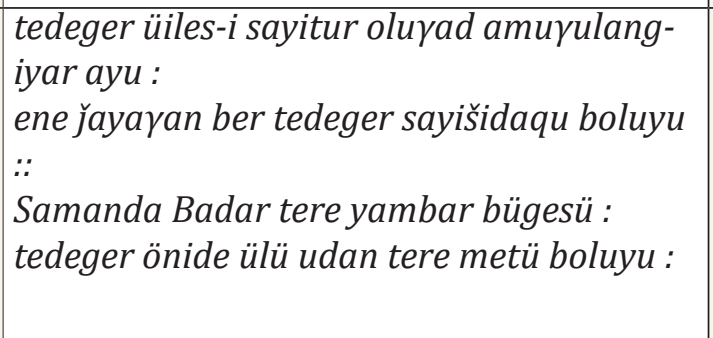 & $(50)$ & $\begin{array}{l}\text { Они обретут [все виды] блага, будут } \\
\text { жить в счастье } \\
\text { И даже в этом рождении будут } \\
\text { благоденствовать. } \\
\text { Вскоре без промедления они } \\
\text { [Смогут] стать подобными бодхисаттве } \\
\text { Самантабхадре. }\end{array}$ \\
\hline (51) & $\begin{array}{l}\text { tabu ǰabsar ügei kilinče-nuүud } \\
\text { ken ülü medekü-yin erkeber üiledüged: } \\
\text { teden ber ene sayin yabudal-un irügel-i } \\
\text { ögülebesü : } \\
\text { uүuүata qočorli ügei ütür arilaqu boluyu :: }\end{array}$ & (51) & $\begin{array}{l}\text { Пусть даже те, кто в силу неведения } \\
\text { совершил } \\
\text { Пять неблагих деяний с немедленным } \\
\text { воздаянием } \\
\text { Произнеся эту молитву-устремление о } \\
\text { благом пути, } \\
\text { Быстро [смогут] полностью таким } \\
\text { образом их очистить! }\end{array}$ \\
\hline$(52)$ & 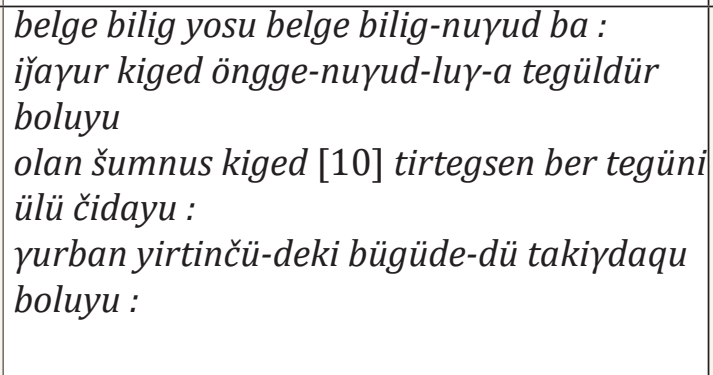 & $(52)$ & $\begin{array}{l}\text { Они будут обладать высшей мудростью, } \\
\text { признаками [высшей личности], } \\
\text { Высоким происхождением и прекрасной } \\
\text { внешностью. } \\
\text { Их не смогут одолеть многочисленные } \\
\text { полчища мар и тиртхиков } \\
\text { И будут почитать повсюду во всех трех } \\
\text { мирах. }\end{array}$ \\
\hline
\end{tabular}

\footnotetext{
${ }^{1}$ Неблагие уделы - три низших мира сансары: ады, мир претов, или голодных духов, и мир животных.

${ }^{2}$ Амитабха - один из пяти дхьяни-будд.

${ }^{3}$ Пять неблагих деяний с немедленным воздаянием - пять тяжелейших проступков с немедленным возданием, после совершения которых человек обретает рождение в адских сферах без пребывания в промежуточном состоянии бардо.

4 Тиртхики - не-буддисты, последователи других учений, те, кто придерживается крайностей неправильных воззрений.
} 


\begin{tabular}{|c|c|c|c|}
\hline (53) & 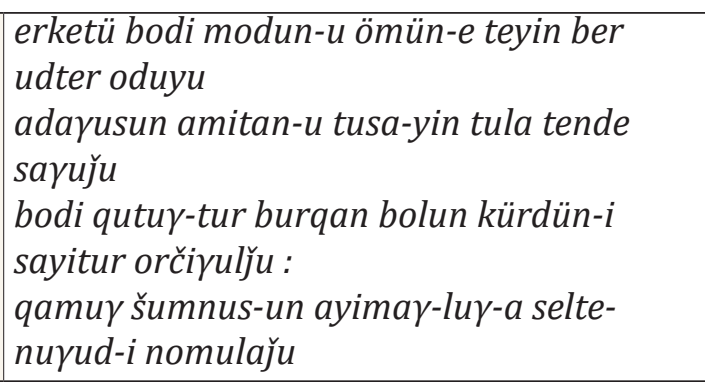 & \begin{tabular}{|l}
$(53)$ \\
\end{tabular} & $\begin{array}{l}\text { Они быстро отправятся под могучее } \\
\text { древо Пробуждения } \\
\text { И будут пребывать там ради блага } \\
\text { живых существ. } \\
\text { Став буддами, они будут совершенным } \\
\text { образом вращать колесо [Учения], } \\
\text { А также усмирят все полчища мар. }\end{array}$ \\
\hline (54) & 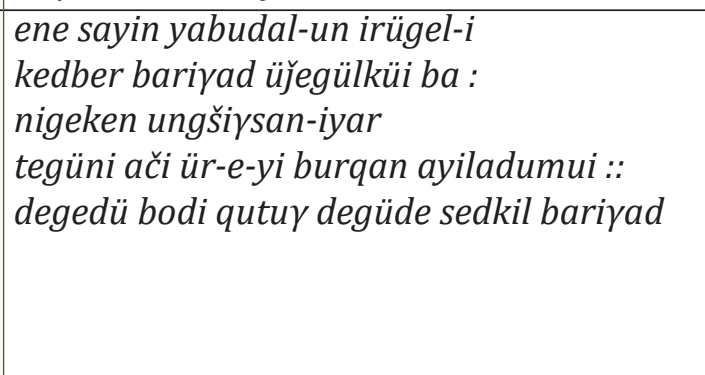 & $(54)$ & $\begin{array}{l}\text { Лишь будды знают, какова польза от } \\
\text { запоминания, } \\
\text { Объяснения или начитывания даже } \\
\text { один раз этой молитвы-устремления о } \\
\text { благом пути. } \\
\text { Не сомневайтесь в [возможности] } \\
\text { Достижения высшего Пробуждения } \\
\text { [благодаря этим действиям]! }\end{array}$ \\
\hline (55) & 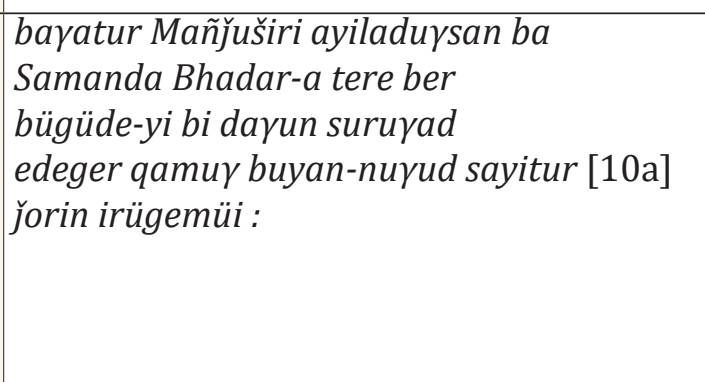 & (55) & $\begin{array}{l}\text { Подобно герою Манджушри, } \\
\text { [достигшему] всеведения, } \\
\text { И Самантабхадре, ставшему подобным } \\
\text { ему, } \\
\text { Я совершенным образом посвящаю все } \\
\text { эти благие заслуги, } \\
\text { Чтобы упражняться и следовать [по их } \\
\text { стопам]. }\end{array}$ \\
\hline (56) & 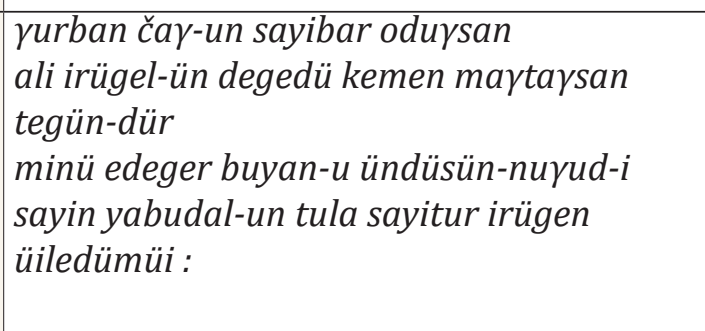 & (56) & $\begin{array}{l}\text { Все Победоносные прошлого, } \\
\text { настоящего и будущего } \\
\text { Восславили [эту] молитву-устремление } \\
\text { как высшую, } \\
\text { Поэтому все корни моих добродетелей } \\
\text { от этого [деяния] } \\
\text { Я посвящаю благому пути. }\end{array}$ \\
\hline (57) & 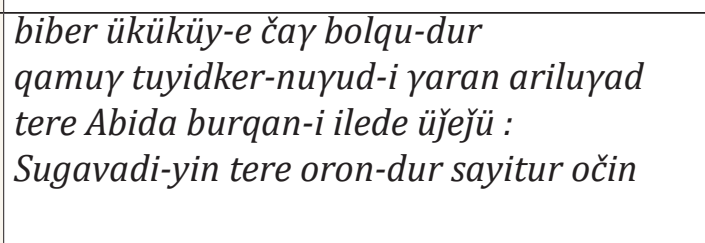 & (57) & $\begin{array}{l}\text { Пусть, когда придет время моей смерти, } \\
\text { Я устраню все завесы сознания, } \\
\text { Узрю воочию Будду Амитабху } \\
\text { И отправлюсь в Чистую Землю } \\
\text { Сукхавати }{ }^{1} !\end{array}$ \\
\hline (58) & 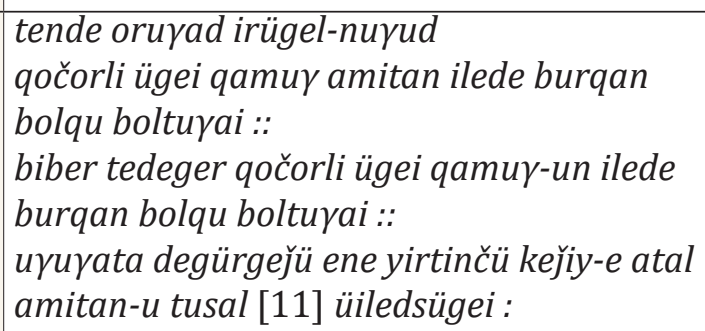 & (58) & $\begin{array}{l}\text { Когда я окажусь там, пусть } \\
\text { Все существа без остатка станут } \\
\text { буддами! } \\
\text { Пусть я полностью исполню достигну } \\
\text { состояния будды } \\
\text { И, покуда [существует] сансара, буду } \\
\text { приносить пользу живым существам! }\end{array}$ \\
\hline
\end{tabular}

${ }^{1}$ Сукхавати - Чистая Земля Будды Амитабхи на западе, в которой существа рождаются в бутоне лотоса, наделены золотыми телами, отмеченными тридцатью двумя благими признаками, и обладают знанием своих предыдущих жизней и различными сверхъестественными способностями. 


\begin{tabular}{|c|c|c|c|}
\hline \begin{tabular}{|l|l}
$(59)$ \\
\end{tabular} & 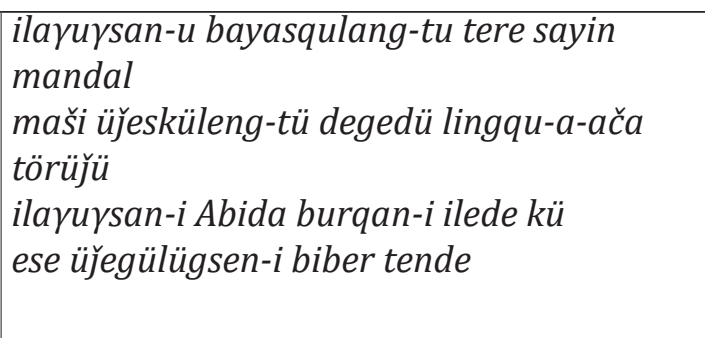 & (59) & $\begin{array}{l}\text { Пусть, родившись в прекрасном и } \\
\text { лучшем из всех цветке лотоса, } \\
\text { В той превосходной исполненной } \\
\text { радости Чистой Земле Победоносных } \\
\text { [Из уст] Будды Амитабхи } \\
\text { Я получу предсказание-вьякарануํㅡㄹ } \\
\text { [достижении] Пробуждения! }\end{array}$ \\
\hline$(60)$ & 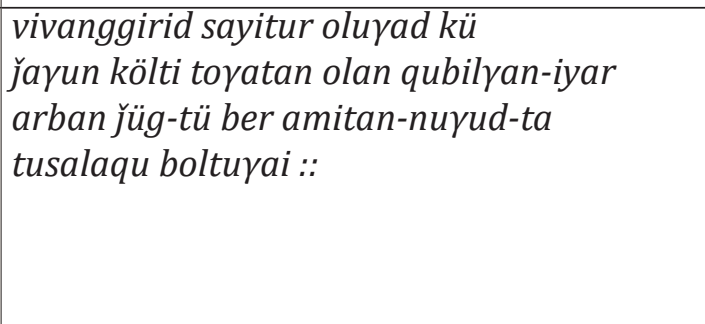 & $(60)$ & $\begin{array}{l}\text { Пусть я, получив превосходное } \\
\text { предсказание-вьякарану } \\
\text { И [создавая] мириады воплощений, } \\
\text { Силой своего ума во [всех] десяти } \\
\text { направлениях } \\
\text { Буду приносить большую пользу живым } \\
\text { существам! }\end{array}$ \\
\hline \begin{tabular}{|l|}
$(61)$ \\
\end{tabular} & 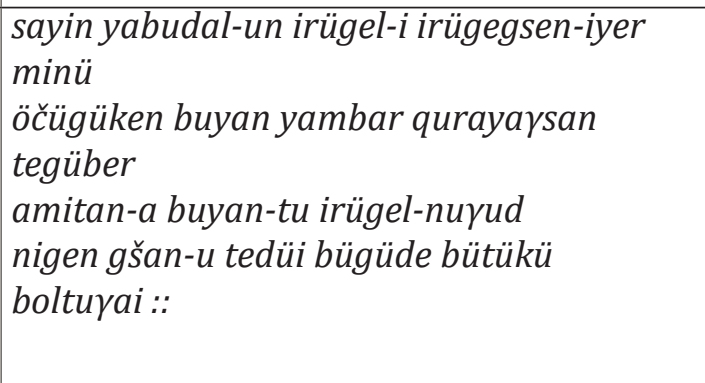 & (61) & $\begin{array}{l}\text { Пусть [силой] тех незначительных } \\
\text { благих заслуг, } \\
\text { Которые я накопил благодаря чтению } \\
\text { этой молитвы-устремления о благом } \\
\text { пути, } \\
\text { Все добродетельные молитвы- } \\
\text { устремления живых существ } \\
\text { Исполнятся в одно мгновение! }\end{array}$ \\
\hline (62) & 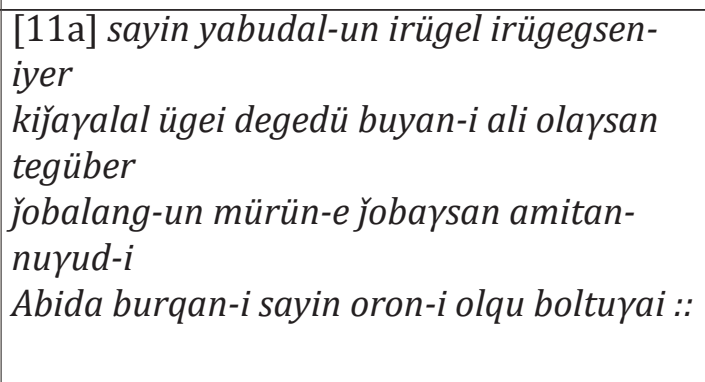 & (62) & $\begin{array}{l}\text { Пусть силой высшей безграничной } \\
\text { благой заслуги, обретаемой благодаря } \\
\text { посвящению заслуг } \\
\text { С помощью этой молитвы-устремления } \\
\text { о благом пути, } \\
\text { Живые существа, тонущие в океане } \\
\text { страданий, } \\
\text { Достигнут обители Будды Амитабхи! }\end{array}$ \\
\hline (63) & 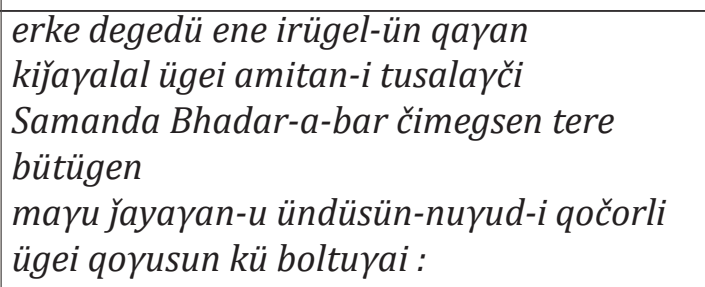 & (63) & $\begin{array}{l}\text { Пусть силой практики Самантабхадры, } \\
\text { [описанной] в «Высшем Царе этих } \\
\text { молитв-устремлений», } \\
\text { Все причины неблагих уделов } \\
\text { полностью исчерпаются! }\end{array}$ \\
\hline
\end{tabular}

${ }^{1}$ Вьякарана - предсказание, разъяснение. После того как бодхисаттва произносит молитвуустремление, Будда произносит предсказание о достижении тем Пробуждения в будущем. 


\begin{tabular}{|c|c|}
\hline 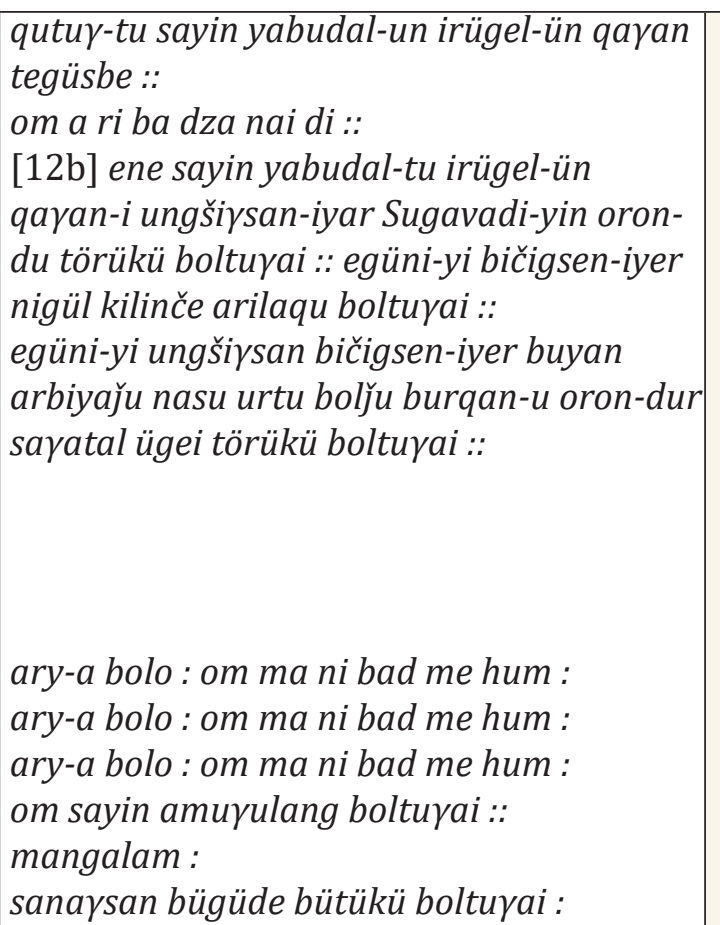 & $\begin{array}{l}\text { «Ыысший Царь молитв-устремлений о } \\
\text { благом пути» завершен. } \\
\text { Ом а ра па ца на ди. } \\
\text { Пусть благодаря чтению этой молитвы- } \\
\text { устремления о благом пути я обрету } \\
\text { рождение в Сукхавати! Пусть благодаря } \\
\text { переписыванию этого [текста] } \\
\text { очистятся все неблагие поступки! } \\
\text { Пусть благодаря чтению и } \\
\text { переписыванию [текста] добродетели } \\
\text { преумножатся, жизнь будет долгой и я } \\
\text { беспрепятственно обрету рождение в } \\
\text { обители будд! } \\
\text { Арья бала. Ом мани падме хум. } \\
\text { Арья бала. Ом мани падме хум. } \\
\text { Арья бала. Ом мани падме хум. } \\
\text { Ом. Да будет благо. } \\
\text { Мангалам. } \\
\text { Пусть все задуманное исполнится! }\end{array}$ \\
\hline
\end{tabular}

\section{Благодарности}

Автор выражает искреннюю признательность Любови Кенденовне Хертек (Тувинский институт гуманитарных и прикладных социально-экономических исследований) и Мире Викторовне Бавуу-Сюрюн (Тувинский государственный университет) за предоставление возможности ознакомиться с текстом рукописи.

\section{СПИСОК ЛИТЕРАТУРЫ / REFERENCES}

Asmussen, J. P. (1961) The Khotanese Bhadracaryādeśanā (Text, translation, and glossary, together with the Buddhist Sanskrit original). Kopenhagen, Bianco Lunos Bogtrykkeri A-S. 97 p.

Kapstein, M. (2000) The Tibetan assimilation of Buddhism: conversion, contestation and memory. Oxford, Oxford Univ. Press. 316 p.

Osto, D. E. (2010) A new translation of the Sanskrit Bhadracarī with introduction and notes // New Zealand Journal of Asian Studies. Vol. 12. No. 2 (December 2010). P. 1-21.

Osto,D.E. (1999) A study and translation of the Samantabhadracaryāpraṇidhānam (prose) of the Gandavyūhasūtra. A thesis submitted ... for the degree of Master of Arts. University of Washington. $118 \mathrm{p}$. 


\section{Для цитирования:}

Мирзаева С. В. Монгольская рукопись «Царя молитв-устремлений о благом пути» («Бхадрачарья») из тувинского архива [Электронный ресурс] // Новые исследования Тувы. 2018, № 4. URL: https://nit.tuva.asia/nit/article/view/814 (дата обращения: дд.мм.гг.). DOI: 10.25178/nit.2018.4.11

\section{For citation:}

Mirzaeva S. V. The Mongolian manuscript of the «Bhadracarya» (The King of Aspiration Prayers, The Aspiration for Noble Excellent Conduct) from a Tuvan archive. The New Research of Tuva, 2018, no. 4 [on-line] Available at: https://nit.tuva.asia/nit/article/ view/814 (accessed: ... ). DOI: 10.25178/nit.2018.4.11 